\title{
ENHANCING THE QUALITY OF LIFE OF OLDER PERSONS WITH AND WITHOUT A DISABILITY THROUGH ADAPTED PHYSICAL ACTIVITY ACROSS EUROPE
}

\author{
Herman Van Coppenolle, Stefka Djobova, Iana Dobreva \\ Faculty of Kinesiology and Rehabilitation Sciences, Leuven Catholic University, Leuven, Belgium
}

\begin{abstract}
Herman Van Coppenolle. Professor, Doctor of Social Sciences. Professor at the Department of Rehabilitation Sciences at Leuven Catholic University. The aspects of the research — psychomotor observation and psychomotherapy for psychiatric patients; the development of a scale for measuring the body attitude in anorexia nervosa patients.
\end{abstract}

\begin{abstract}
Research data estimate that by the end of 2040 the severely impaired adults will be $6.5 \%$ of the total population in Europe, or 24.5 million people. Today $7.5 \%$ of the total European population is 75 years old and more. In 30 years this percentage will rise to $14.4 \%$. Ageing is a process that often affects and restricts the people who are growing old, on physical, psychological and social level. As older adults are the fastest growing group, attention needs to be given to them as a special population in the area of exercise and sport. The review article aims to present research data in intervention and prevention of disease and disability in older persons through adapted physical activity as well as analyze some theoretical models for changing physical inactivity into an active lifestyle in older people. As analysis of literature showed, all older adults at all ages should be encouraged to move more, and increase aspects of physical activity in their lives; this may be balance and posture, strength training, or moderate or / and vigorous intensity activities, but it is important to maintain a regular habit throughout older years. Specific targets should be tailored to the capacity, the motivation, expectations and confidence in older individuals, in all societies and demographic groups. The research data about the benefits of physical activity are clear and convincing. Till now there is a need to act and find the best strategy and policy to realize this active lifestyle leading to a better health and more well-being.
\end{abstract}

Keywords: ageing, disability, adapted physical activity, thematic network.

\section{INTRODUCTION}

$\mathrm{O}$ ne of the most important changes in Europe over the last 50 years has been the rapid increase in the number of people living into their $70 \mathrm{~s}, 80 \mathrm{~s}$ and beyond. Also the life expectancy of the persons with a disability has tremendously increased. Most of the ageing people have some physical and mental disability; regardless the fact if they acquired this disability at birth or obtained it later in life or just as it happened as a consequence of the normal process of ageing.

The 'Eurostat' data estimate that by the end of 2040 the severely impaired adults will be $6.5 \%$ of the total population in Europe, or 24.5 million people. Today $7.5 \%$ of the total European population is 75 years old and more. In 30 years this percentage will rise to $14.4 \%$ (WHO, 2002).

Recently the traditional disability model has changed to agree with the suggestion that disability develops not only from disease but also from lifestyle choices.

Ageing is a process that often affects and restricts the people who are growing old, on physical, psychological and social level. As older adults are the fastest growing group, attention needs to be given to them as a special population in the area of exercise and sport. Qualified professionals in the area of physical activity for the elderly have to be prepared now, so they can meet the new demands of the future (Djobova et 
al., 2004).

A Thematic Network is needed to create a basic profile and implement the subject of adapted physical activity (APA) for the elderly in the European Higher Education curricula, in order to compensate for the current lack of information and resources in that specific domain (Dobreva et al., 2004).

A second task of this Thematic Network will be to stress the research data of Adapted Physical Activity intervention (for the older persons with a disability) and the prevention (for the older persons without an actual disability) by keeping them as physically active as possible, which indeed can delay the onset of disease and disability.

The most important task however will be the implementation of the best methods and policies in keeping older persons physically active in all European countries. This will be done by first making a comparative study of the actual situation in each country, and constructing out of this comparison the ideal model which should then be implemented in all European countries.

The review article aims to present research data in intervention and prevention of disease and disability in older persons through adapted physical activity as well as analyze some theoretical models for changing physical inactivity into an active lifestyle in older people.

\section{Research data in intervention of disabled persons through adapted physical activity}

The benefits of adapted physical activity for all persons with chronic diseases and disabilities and the research done to prove these benefits are well known and listed in many articles and books.

They are of course the subject of Master programmes in Adapted Physical Activity, for example the Erasmus Mundus and European Master in Adapted Physical Activity, co-ordinated by the university of Leuven (Belgium) which has a course titled "Applied Research in Adapted Physical Activity: State of the Art" (Van Coppenolle et al., 2004). These benefits are of course independent of the age of the persons with chronic diseases and disabilities, and are also applicable for older persons, taking into consideration their advanced age.

An excellent book of the American College of Sports Medicine "Exercise Management for Persons with Chronic Diseases and Disabilities"
(Durstine and Moore, 2003) gives a large overview of scientifically based exercise management for several diseases and disabilities such as cardiovascular diseases, pulmonary diseases, metabolic diseases, immunological / hematological disorders, orthopedic diseases and disabilities, neuromuscular disorders, and cognitive, psychological and sensory disorders. Starting from the problem-oriented exercise management, the authors advise exercise tests, measures and recommend exercise programming for all diseases and disabilities of all ages including the elderly population.

\section{Research data in prevention of disease and disability in older persons through adapted physical activity}

In another excellent book "Optimizing Exercise and Physical Activity in Older People" (Morris and Schoo, 2004), a state of the art of the most recent epidemiological research is given in understanding and monitoring physical activity among older adults.

The health benefits associated with physical activity in elderly people are part of "successful ageing" which is concerned with disease preventions but more important among older adults, with delaying the declines in age-related function (Chodzko-Zajko, 2000; Wagner et al., 1992). The World Health Organization has concluded that physical activity is the single most useful thing that individuals can do to maintain their health, function and quality of life (WHO, 1997). The evidence is the strongest for cardiovascular diseases, especially coronary heart disease, where moving the population from inactive to moderate activity levels, can reduce the risks of incident and fatal CHD by around 40$50 \%$. The evidence is also good for diabetes, across all levels of prevention.

The physiological benefits are diverse, but most notable are significant impacts on reducing blood pressure, and increases in muscle strength (Wagner et al., 1992). The latter has an impact on the risk of injurious falls, as well as being related to functional outcomes and the performance of daily tasks.

The psychological benefits include selfesteem and a sense of mastery, improved mood, and reduction of depression for those who had initially high levels. There are also policy-relevant benefits on health care costs and morbidity 
(Perkins and Clark, 2001). This provides a rationale for European and world-wide interventions to encourage activity among older adults.

The social benefits, although least researched, are important. These include the potential for greater empowerment of older adults, better integration into communities, the formation of social networks and connections, and increased engagement with others (WHO, 1997).

Finally, there is no simple final recommendation that fits all health outcomes, for all ages of older adulthood.

The most pragmatic public health recommendation is that all older adults at all ages should be encouraged to move more, and increase aspects of physical activity in their lives; this may be balance and posture, strength training, or moderate or / and vigorous intensity activities, but it is important to maintain a regular habit throughout older years.

Specific targets should be tailored to the capacity, the motivation, expectations and confidence in older individuals, in all societies and demographic groups.

From research into practice theoretical models for changing physical inactivity into an active lifestyle in older people

Despite the now substantial evidence that physical activity can improve health in later life through risk factor modification, promoting physical activity as an important health and wellbeing factor for older people, has not had the focus it deserves (Minkler et al., 2000).

Inactivity contributes to 200.000 deaths per year in the USA (Sallis, 2001) and in Australia physical activity is the second most important area for risk factor reduction with regard to the overall burden of disease (AIHW, 2000; Bauman and Smith, 2000).

In promoting physical activity and exercise, health professionals attempt to elicit behaviour change. This may involve encouraging older people to increase the amount of activity in their every day life through walking and other moderate activities, prescribing specific exercises to improve balance and strength (Bauman and Smith, 2000) or prescribing specific exercises for rehabilitation after injury.

Whether working with older patients with chronic diseases or disabilities or those who are relatively healthy, in order to promote health and well-being, the practitioner needs to understand the prescribed therapy / intervention in terms of how to assist the person to adopt new behaviours. As pointed out by S. Rollnick et al. (2000) it is not sufficient simply to give people advice and expect that the authority of the health professional will translate into behavioural change.

Several models can usefully inform this discussion as the health belief model, the theory of planned behaviour, health locus of control / self-efficacy.

In the health belief model is stated that if you consider an illness not to be serious or unlikely to occur, it is unlikely that you will invest in a major effort to avoid it. In this context the health professional should provide information about the severity of the problem and the persons susceptibility to disease or disability, provide cues to action by providing information about the negative consequences of the disease, provide information about the positive consequences of the preventive actions (benefits), and address barriers to action.

This cognitive model provides a common sense approach to behavioural change and has contributed to a range of interventions over the last 30 years.

The theory of reasoned action / planned behaviour asserts that the person's intention to perform a particular action is the best predictor of whether they will perform that action. In other words, what you intend to do, you are likely to do (Ajzen and Fishbein, 1980).

If the person believes that exercise is a good thing to do, because it is likely to lead to health benefits and the person's friends and family themselves exercise, and they believe that they have access to resources/opportunities to perform the target behaviour, then it is likely that they will form a behaviour intention to exercise. A behaviour change programme based on this model would try to change the negative beliefs in a positive way.

Other models of health behaviour change are based on the related concepts of health locus of control and self-efficacy. This model assumes that people's beliefs about whether they can control what happens to them through their own actions, influence behaviour. People with high internal locus of control tend to believe that their destiny (health) is controlled by their own actions. 
Individuals with high external locus of control may be less motivated to change their behaviour or to take preventive health actions because they believe that it is likely to be ineffective. Why worry then when you can't change things.

The health locus of control is quite similar to the theoretical construct of self-efficacy (Bandura, 1994) with one important difference. Health locus of control is assumed to be generalized, like a personality trait. On the other hand, efficacy is content specific. Within the self-efficacy framework, high self-efficacy beliefs are associated with a propensity to change specific health behaviours and take action, whereas low self-efficacy beliefs are not.

Health behaviour change interventions based on the health locus of control and the self-efficacy models should focus on convincing the person that they have the personal resources required to act in the required manner. Behaviour change is also fundamental to the concept of self-management of disease and disability that has its origins in the important role of patient education in health care (Holman and Lorig, 2000).

Self-management is recognised as a common model for managing chronic disease and changing health behaviours. M. Battersby et al. (2002) and P. Jyasuriya et al. (2001) provide a comprehensive review of the chronic disease management literature. Physical activity is a significant component of many self-management programmes, especially in the older adult population where those over 65 have at least one chronic health condition such as diabetes, cardiovascular disease, musculoskeletal problems or decreased mental health (Australian Institute for Health and Welfare, 2000; World Health Organization, 2002).

One of the most reliable findings with physical activities is that people feel better (Chodzo-Zajjko et al., 1999). As a result, finding ways to increase the willingness of people to assume responsibility for their own health and not rely on a "magic bullit" to cure their ills must be a priority.

Self-management is essential in all aspects of life and taking control over physical activity is a major step towards overall control. Health professionals have an important role to play in the initiation and support of self-management behaviours in old age, and helping clients change their physical activity behaviours is central to improving function and quality of life.

From a policy perspective, older adults have been considered to be a special group, but what must be noted is that with the ageing of the babyboomers, older people will comprise a significant proportion of the total population.

In a world environment that will be dominated by older adults, promoting healthy or active living has become a focus for governments world-wide (Browning and Kendig, 2003; World Health Organization, 2002).

European thematic networks to achieve the ideal profile in all countries at the same time

Changing behaviours in realizing the objective to change inactivity of the older persons with and without a disability into adopting an active lifestyle is not an easy task and requires a structural approach, this means a European-wide co-operation. First in educating students in adapted physical activity throughout similar programmes across Europe. This objective was realized in the First Thematic Network (THENAPA I) "Educational and Social Integration of Persons with a Disability through Adapted Physical Activity" (Van Coppenolle et al., 2004) (1999-2004) through the hard work of all national key-persons after the 7 Forums in: Leuven (Belgium), Oslo (Norway), Lahti (Finland), Porto (Portugal), Budapest (Hungary), Brussels (Belgium), and Sofia (Bulgaria).

In these meetings, experts from 23 countries agreed on a common European programme for the training of bachelors and masters in physical education, physiotherapy, sports and recreation by producing the content and the form of such a programme in a very attractive visual way, the CD-ROM “ADAPT" (Djobova et al., 2004; http:/ /www.kuleuven.ac.be/thenapa/adapt.htm).

This CD-ROM of which 20.000 copies were produced is available in 15 European languages and will be used as the basic instruction tool for all European students. In this way students will be prepared in adapted physical activity in order to enhance the quality of life of all persons with a disability, including older persons.

The following chapters in the CD-ROM "ADAPT" cover the basics of Adapted Physical Activity (APA) and Sports concerning: general concepts of APA; applied human / sport sciences to APA; applied assessment / evaluation; applied knowledge of disability, impairment and handicap; 
APA and sports techniques; applied research methodology; APA training programming; classification systems; social environment and accessibility, facilities and equipment (Djobova, Dobreva, Van Peteghem, Van Coppenolle, 2004).

At the same time these experts approached their universities, ministries of education, sports and health for improving the integration and the promotion of adapted physical activity and sports for persons with a disability (including older persons) (De Potter et al., 2004).

The European Commission supports of course in a maximal way the recommendations of this Thematic Network (translated in all European languages) and its concrete implementation (Van Coppenolle et al., 2004).

In addition to the first CD-ROM "ADAPT" a second CD-ROM ("ADAPT II") "Examples of Good Practice in Adapted Physical Activity" was developed in order to motivate in the first place the persons with a disability themselves (also older persons) to participate in different adapted physical activities, by trying to attract them to participate in different games and sports at recreational and competitive level (Dobreva and Djobova, 2004).

With this objective in mind this CD-ROM brings a summary of video films concerning good practices in ballgames, dance, water sports, athletics, winter sports, hippo therapy, Special Olympics and triathlon.

Another European project performed in the Year of Education through Sport (2004) "Sports Participation for Inclusion of Persons with a Disability" made it also possible to produce the CD-ROM "ADAPT" in 12 more languages and to make a European website with information of adapted physical activity programmes for all persons with a disability at school and in the sport clubs in 20 European countries (Van Coppenolle et al., 2004; http://www.adapt-europe.org). In all these projects, Prof. R. Adomaitiene and her staff of the Lithuanian Academy of Physical Education in Kaunas had a major contribution.

Implementing and researching the effects of an ideal strategy and policy in all European countries

More specifically directed to older persons with and without a disability, is the start of a new European Thematic Network (THENAPA II) (64 partner universities from 29 European countries)
(2004-2007) "Ageing and Disability - A New Crossing between Physical Activity, Social Inclusion and Life-Long Well-being" (Van Coppenolle et al., 2004).

This network which was started up in Malta in December 2004, brings together experts in APA and experts in theory and practice of physical activity in older persons in order to better prepare students in physical education, physiotherapy, sports, recreation, occupational therapy, nursing, etc. Also to activate physical activity in older persons both as intervention and as prevention for all kind of diseases and disabilities linked to physical inactivity. In this way they will as well contribute to an enhanced quality of life and wellbeing of these older persons.

This topic will of course also be included in the European and the Erasmus Mundus Master Course in Adapted Physical Activity, co-ordinated by the university of Leuven and covering with the just selected new Erasmus Mundus Master, an unique opportunity to spread out this message as well on a world level.

The main objective of this network however should be to develop strategies for a complete change of the policy in all European countries at the same time in approaching older persons with and without a disability by convincing them to be more physically active.

Therefore in the first year of the network a comparative study should be made of the best strategies followed in Europe and other parts of the world to get older persons more active.

In the second year an ideal strategy and policy should be defined which should then be implemented and evaluated in all European countries.

This process will be followed-up by a comprehensive research study on the effects of the implemented "ideal policy".

It is our privilege to be the co-ordinators of all these European Networks and European and Erasmus Mundus Master Programmes and in this way to be able with the help of our partners from all European countries, to realize this so important change for all older persons.

The research data about the benefits of physical activity are clear and convincing. Now we must act and find the best strategy and policy to realize this active lifestyle leading to a better health and more well-being. 


\section{REFERENCES}

Ajzen, I. \& Fishbein, M. (1980). Understanding Attitudes and Predicting Social Behaviour. Englewood Cliffs, New Jersey: Prentice Hall.

Australian Institute of Health and Welfare (AIHW). (2000). Disability and Ageing: Australian Population Patterns and Trends. Canberra: AIHW.

Bandura, A. (1994). Self-Efficacy: Thought Control of Action. New York: Freeman.

Battersby, M., Reece, M., Higgins, P. \& Markwick, M. (2002). What is Self-Management? Flinders University Coordinated Care Training Unit.

Bauman, A. E. \& Smith, B. J. (2000). Healthy ageing: What role can physical activity play? Medical Journal of Australia, 173 (2), 88-90.

Browning, C. \& Kendig, H. (2003). Healthy ageing: A new focus on older people's health and well-being. In P. Liamputtong \& H. Gardner (Eds.), Health Care Reform and the Community. Sidney: Oxford University Press.

Chodzko-Zalko, W., Beling, J., Bortz, W. et al. (1999). The 1999 Albert and Elaine Borchard Symposium: The Future Role of Regular Physical Activity in Successful Ageing. Internet link: http://www.isapa.org/borchard.

Chodzko-Zajko. (2000). Successful ageing in the new millennium; the role of regular physical activity. Quest, $52,333-343$.

Van Coppenolle, H., De Potter J. C., Djobova, S., Dobreva, I. (2004). Thematic Network Educational and Social Integration of Persons with a Disability through Adapted Physical Activity. Internet link: http:// www.kuleuven.ac.be/thenapa/education/index.htm.

Van Coppenolle, H., De Potter, J. C., Van Peteghem A., Djobova, S., Wijns, K. (2004). Inclusion and Integration through Adapted Physical Activity. Leuven: Acco.

Van Coppenolle, H., Djobova, S., Dobreva, I. (2004). Erasmus Mundus Master in Adapted Physical Activity, K. U. Leuven: Faculty of Kinesiology and Rehabilitation Sciences (Tervuursevest, 101, 3001 Leuven-Heverlee, Belgium).

Van Coppenolle, H., Djobova, S., Dobreva, I. (2004). Sportsparticipation for Inclusion of Persons with a Disability. Internet link: http://www.adapt-europe.org.

Van Coppenolle, H., Dobreva, I., Djobova, S. (2004). Ageing and Disability - A New Crossing between Physical Activity, Social Inclusion and Life-Long WellBeing, K. U. Leuven: Faculty of Kinesiology and Rehabilitation Sciences (Tervuursevest, 101 LeuvenHeverlee, Belgium).

Djobova, S., Dobreva, I., Van Peteghem, A. \& Van Coppenolle, H. (2004). ADAPT CD-ROM - a new educational tool in Adapted Physical Activity. Isokinetics and Exercise Science, 12 (1), 68-69.

Djobova, S., Van Peteghem, A., Wijns, K., Dobreva, I. \& Van Coppenolle, H. (2004). ADAPT, European Curriculum in Adapted Physical Activity. Internet link: http://www.kuleuven.ac.be/thenapa/adapt.htm

Djobova, S., Dobreva, I., Van Peteghem, A. \& Van Coppenolle, H. (2004). Ageing and disability - a new crossing between physical activity, social inclusion and life-long well-being. Isokinetics and Exercise Science, 12 (1), 39-40.

Dobreva, I., Djobova, S. \& Van Coppenolle, H. (2004). Ageing and disability — do we need this as a subject in the Higher Education Curriculum. Book of Abstracts, $7^{\text {th }}$ Annual Congress, European College of Sport Science, Clermont-Ferrand, 42.

Dobreva, I., Djobova, S. (2004). ADAPT II Examples of Good Practice in Adapted Physical Activity and Sports, Faculty of Kinesiology and Rehabilitation Sciences (Tervuurse Vest, 101, 3001). Belgium: Leuven-Heverlee. Durstine, J. \& Moore, G. (Eds.) (2003). Exercise Management for Persons with Chronic Diseases and Disabilities. Human Kinetics: American College of Sports Medicine.

Holman, H. \& Lorig, K. (2000). Patients as partners in managing chronic disease. British Medical Journal, 320, $526-527$.

Jyasuriya, P., Roach, S. \& Shaw, E. L. B. (2001). SelfManagement and Chronic Disease. Royal Australian College of General Practitioners. Internet link: http:// www.racgp.org.au/document.asp?id=3926

Minkler, M., Schauffer, H. \& Clements-Nolle, K. (2000). Health promotion for older Americans in the $21^{\text {st }}$ century. American Journal of Health Promotion, 14, 371-379.

Morris, M. \& Schoo A. (Eds.) (2004). Optimizing Exercise and Physical Activity in Older People. ButterworthHeinemann: Elseviers Science.

Perkins, A. J. \& Clark, D. O. (2001). Assessing the association of walking with health services use and costs among socioeconomically disadvantaged older adults. Preventive Medicine, 32, 492-501.

De Potter, J. C., Van Coppenolle, H., Van Peteghem, A., Djobova, S. \& Wijns, K. (2004). Vocational Training in Adapted Physical Activity. Leuven: Acco.

Rollnick, S., Mason, P. \& Butler, C. (2000). Health Behaviour Change: A Guide for Practitioners. Edinburgh: Churchill Livingstone.

Sallis, J. (2001). Progress in behavioural research on physical activity. Annals of Behavioural Medicine, 43, $23-77$.

Wagner, E. H., La Croix, A. Z. et al. (1992). Effects of physical activity on health status in older adults I: Observational studies. Annual Review of Public Health, $13,451-468$.

World Health Organization. (1997). Heidelberg guidelines for promoting physical activity among older persons. Journal of Ageing and Physical Activity, 5, 2-8.

World Health Organisation (WHO). (2002). Active Ageing: A Policy Framework. Geneva: WHO. 


\title{
EUROPOS PAGYVENUSIŲ IR SENYVŲ NEIGGALIŲ ŽMONIŲ GYVENIMO KOKYBĖS GERINIMAS TAIKOMĄJA FIZINE VEIKLA
}

\author{
Herman Van Coppenolle, Stefka Djobova, Iana Dobreva \\ Leveno kataliku universitetas, Levenas, Belgija
}

\begin{abstract}
SANTRAUKA
Tyrimo duomenys rodo, kad iki 2040 metų sunkiai sergantys suaugusieji sudarys $6,5 \%$ arba pasieks 24,5 milijonus visos Europos populiacijos. Šiandien 7,5\% visų Europos gyventojų yra 75 metų ir vyresni. Per 30 metu šis skaičius išaugs iki 14,4\%. Senejjimas yra procesas, fiziškai, psichologiškai, socialiai veikiantis ir ribojantis senstančius žmones. Pagyvenę žmonès yra greičiausiai auganti socialinè grupè, todèl būtina skirti ypatingą dèmesi jų fizinei veiklai ir sportui. Apžvalginiame straipsnyje pateikiami tyrimo duomenys, kaip palengvinti negalią ar išvengti ligu taikomaja fizine veikla. Straipsnyje taip pat analizuojami kai kurie teoriniai modeliai, kurie padètų senyvų žmonių neveiklumą pakeisti aktyviu gyvenimo būdu. Literatūros analizè rodo, kad visi pagyvenę žmonès turètų būti skatinami kuo daugiau judèti ir šitaip pagerinti savo fizinę būseną. Senstant labai svarbu išlaikyti taisyklingą kūno pusiausvyrą ir laikyseną, būtina treniruoti jègą arba užsiimti neintensyvia ir judria veikla. Šie tikslai turètų atitikti pagyvenusių žmonių pajègumą, motyvacija, lūkesčius ir pasitikèjimą visose visuomenès ir demografinèse grupèse. Tyrimo medžiaga akivaizdžiai rodo fizinès veiklos privalumus. Todèl būtina veikti ir rasti geriausią strategiją ir politiką, aktyvaus gyvenimo būdą, padedantị siekti geresnès sveikatos ir savijautos.
\end{abstract}

Raktažodžiai: senėjimas, taikomoji fizinè veikla, teminis tinklas.

Gauta 2004 m. lapkričio 7 d.

Received on November 7, 2004

Priimta $2005 \mathrm{~m}$. vasario $2 \mathrm{~d}$.

Accepted on February 2, 2005

\author{
Herman Van Coppenolle \\ Faculty of Kinesiology and Rehabiliatation Sciences \\ Tervuurse Vest 101 \\ B 3001 Leuven, Belgium \\ $\mathrm{Tel}+3216329126$ \\ E-mail herman.vancoppenolle@faber.kuleuven.be
}

